In connexion with Lolemi, Professor W. J. Samarin (now in Leiden, Holland) has undertaken a study of ideophones in Bantu, as part of a more general study of ideophones in African languages. Persons interested in acquiring a copy of a ten-sentence questionnaire for a comparative study of ideophones should write to Professor Samarin at the AfrikaStudiecentrum, Stationsplein ro, Leiden.

\title{
Committee on African Studies, University of Washington, Seattle
}

AN interdepartmental undergraduate and graduate program in African studies is now being developed at the University of Washington. Its major orientation is initially in anthropology and sociology but the program expects to develop training in political science and linguistics as well as in other areas. No degree is offered in African studies; regular work is taken through the departments, but the student has the opportunity to develop an African speciality. The program covers Africa South of the Sahara as a whole. The teachers include: Professor Simon Ottenberg (Anthropology, West Africa, social change, political anthropology); Professor Edgar Winans (Anthropology, East Africa, ecology, social change, political anthropology and law); Professor Peter Wilson (Madagascar, cultural anthropology, ethnohistory); Professor Pierre van den Berghe (Sociology, Southern Africa, social stratification, race relations, social change); Professor James Crutchfield (Economics, fishing resources); Professor Jon Bridgman (History, German African History); Professor John Williams (History, South Africa), Mr. William Nash (Library). For further information on the program write to Professor Simon Ottenberg, Department of Anthropology, University of Washington, Seattle, Washington 98105 , U.S.A.

\section{African Studies in Poland I}

OvEr the last ten years political changes in Africa have made it a focus of scientific interest in Poland. In 1956 the Polish Ethnological Society organized its first post-war seminar on African problems (Wroctaw, 9-I I May). The quarterly Kultura i Spoleczeristwo, started in 1957 by the Research Centre for Sociology and History of Culture of the Polish Academy of Sciences, has brought Africa into the wider sphere of research on contemporary culture. This periodical, connected with sociologists at the University of Lódz, was the first to present African problems from the contemporary as well as the ethnographic viewpoint. Until the mid-nineteen-fifties the interests of Polish scholars did not extend beyond Arabic Africa and Ethiopia. In Polish periodicals a peak of interest in African problems was reached in 1961 .

In 1960 a Department for African and Asian countries was established in the Polish Intitute of International Affairs and in 1964 the Department of African Countries was formed, under the Directorship of Dr. Jerzy Procopczuk, to deal with African political, economic, and social problems. At the University of Warsaw research on African problems is co-ordinated in the Centre for African Studies founded in May 1962 and headed by Professor Stefan Strelcyn. The centre runs post-graduate courses and co-operates with specialists at other centres for 'inter-disciplinary' seminars. Results of research are published in the bulletin Africana in English and French.

The Chair of Semitic Philology in the Institute for Oriental Studies is concerned with the languages and culture of Ethiopia, but research in Arabic is also conducted. Research on the Egyptian and Coptic languages is through the Chair of the Philology of the Ancient East. Practical study of Hausa, Swahili, Amharic, and Bambara is also available. Professor Kazimierz Michatowski, holder of the Warsaw University Chair in Mediterranean

1 See also Africa, xxxii. 2, 1962, p. 173; xxxv. 1, 1965, p. 101; xxxvi. I, 1966, pp. 86-87. 
Archaeology, has made an important contribution to African archaeology in the discovery of Tel Atrib and excavations in Alexandria. Recent work in Africa, connected with the researches on ancient cultures in the areas to be flooded on the construction of the Asswan Dam, include studies of the early Christian cathedral at Farras (eighth to eleventh centuries) with its unique collection of frescoes of unsurpassed historical and artistic value. African geographical studies have been concentrated at the Research Centre for Africa in the Geographical Institute of the University of Warsaw.

African studies are also undertaken at the Universities of Łódź, Toruń, Poznań, Wrocław, Cracow, and Lublin.

(Abridged from 'Polish Research Centres for African Studies', by Antoni Grzybowski, Przeglad Socjologiczny, xix. I, 1965, pp. 287-95)

\section{Polish Sociological Review: Special Issue on Contemporary Africa}

A SPECIAL number of the Polish Sociological Review (Przeglad Socjologiczny, tome xix. I, 1965 ), intended to sponsor discussion of African countries and cultures in the curriculum of Polish universities, has been devoted to papers on emerging Africa prepared by research workers of the Research Centre for African Studies, Polish Academy of Sciences, Warsaw. A paper by Mr. Mokpopo Dravi from Togoland, who studied at the University of Warsaw, is also included. The special number is offered as a contribution to the understanding of the formation of nationalities in contemporary Africa in the sense of Znaniecki's Modern Nationalities (1952). Relations between various systems of cultural values and antagonistic systems of political power are discussed and research is aimed at discovering forces working for harmonious co-operation.

\section{Educational Research in Mwanza}

A RESEARCH-TEAM of the Centre for the Study of Education in Changing Societies in Amsterdam is engaged in a study of the influence of education (mainly primary education) on the personality of the younger generation in the Mwanza district, i.e. in Mwanza town and a rural area some twelve miles to the south. The team consists of a geographer, a sociologist, an anthropologist, a psychologist, and an educationalist. The final report of the team is due to appear in 1969.

\section{(Communicated by Professor J. van Baal)}

\section{The West African Archaeological Newsletter}

Frve numbers of this newsletter have now been produced since its first appearance in December 1964. The first four numbers contain articles and reports of current excavations in West Africa by British and French archaeologists in English and French with summaries in the other language. As it is not on public sale the contents may not be quoted without the original author's permission. The fifth number (November 1966) is devoted to an account of the meeting of West African Archaeologists held at Fourah Bay in June I 966 (reported in Africa, xxxvi. 4, p. 442). It was agreed at this meeting that sufficient good material was now being produced in West Africa to warrant the creation of a professional archaeological journal, and a committee was set up. In the meantime the Newsletter is available for private circulation only and may be obtained from the Editor, Professor Thurstan Shaw, Institute of African Studies, University of Ibadan, Nigeria. 